\title{
PERANAN PEMBELAJARAN DARING KELAS III SD FREE METHODIST-2
}

\author{
Dewi Ulina Ginting ${ }^{1}$, Rumiris Lumban Gaol ${ }^{2}$, Dyan Wulan Sari HS ${ }^{3}$, Patri Janson Silaban ${ }^{4}$ \\ 1,2,3,4 Universitas Katolik Santo Thomas Medan, Indonesia \\ ${ }^{1}$ dewi_ulina@gmail.com, ${ }^{2}$ rumiris20lumbangaol@gmail.com, ${ }^{3}$ dyanwulans@yahoo.com, \\ ${ }^{4}$ vpatri.jason.silaban@gmail.com
}

\begin{abstract}
ABSTRAK
Penelitian ini bertujuan untuk mengetahui peranan pembelajaran daring kelas III SD Free Methodist 2 Medan Tahun Pembelajaran 2020/2021. Bentuk penelitian ini adalah bentuk penelitian kualitatif deskriptif. Subjek dalam penelitian ini adalah siswa kelas III SD Free Methodist 2 Medan. Teknik pengumpulan data dalam penelitian ini adalah teknik observasi, teknik wawancara dan teknik dokumentasi. Berdasarkan penelitian yang telah dilakukan di SD Free Methodist 2 Medan, dapat diambil kesimpulan bahwa, pembelajaran daring efektif dilaksanakan saat adanya pandemi karena untuk memutus penularan virus corona. Dan sebaiknya guru kalau membuat modul materinya harusnya lengkap jangan pula saat membuat pertanyaan siswa mencari jawaban dari google, karena saat pandemi ini sebaiknya siswa dilatih untuk mencari jawaban dari catatannya saja. Lalu sebaiknya saat masa pandemi ini guru harus berperan aktif kepada siswa, dimana guru melakukan videocall sama siswanya jangan hanya mengirim tugas di grup WhatsApp saja. Hasil pembahasan dari penelitian yang sudah dilakukan oleh penelit di SD Free Methodist 2 Medan menyebutkan bahwa pembelajaran daring efektif dilaksanakan saat pandemi untuk memutuskan rantai virus corona dan siswa berprestasi merasa bosan dengan pembelajaran daring karena mereka kurang memahami materi yang diberikan oleh guru. Mereka lebih memahami jika saat diberikan materi dijelaskan atau diterangkan oleh guru karena menurut mereka lebih gampang memahami saat dijelaskan atau diterangkan oleh guru karena saat pembelajaran daring orangtua tidak mampu untuk menjelaskan materi yang diberikan oleh guru.
\end{abstract}

Kata Kunci: peranan, pembelajaran, daring

\section{THE ROLE OF ONLINE LEARNING AT GRADE III OF SD FREE METHODIST-2}

\section{ABSTRACT}

This study aimed to determine the role of online learning at grade III of SD Free Methodist 2 Medan for the academic year 2020/2021. This research was descriptive qualitative research. The subjects in this study were third-grade students of SD Free Methodist 2 Medan. Data were collected through observation, interviews, and documentation. Based on the research results, it was concluded that online learning was effectively carried out during the pandemic as a break the transmission of the coronavirus. Then, it was suggested for the teacher to make a module. It should be complete so that students would not be looking for answers from Google when gen the questions. During this pandemic, students should be trained to look for answers from their notes. Then, during this pandemic period, teachers should play an active role with students, where teachers made video calls with students, not just sent assignments in WhatsApp groups. The results of the discussion stated that online learning was effectively carried out during a pandemic to break the chain of the coronavirus as well as to anticipate students to feel bored with online learning because they did not understand the material given by the teacher. They understood better when the teacher explained the material because they thought that it was easier to understand when the teacher explained the material. Meanwhile, during the process, most of the time it was the parents who explained the material given by the teacher.

Keywords: role, online learning

\begin{tabular}{|c|c|c|}
\hline Submitted & Accepted & Published \\
\hline 12 Agustus 2021 & 19 Oktober 2021 & 24 November 2021 \\
\hline
\end{tabular}

\begin{tabular}{|l|l|l|l|}
\hline Citation & $:$ & Ginting, D.U., Gaol, R. L., Sari HS, D.W., \& Silaban, P.J. (2021). Peranan Pembelajaran Daring Kelas III SD Free \\
& $\begin{array}{l}\text { Methodist-2. Jurnal PAJAR (Pendidikan dan Pengajaran), 5(6), } \\
\text { http://dx.doi.org/10.33578/pjr.v5i6.8511. }\end{array}$ \\
\hline
\end{tabular}

\section{PENDAHULUAN}

Pendidikan merupakan salah satu usaha untuk mencerdaskan kehidupan bangsa dan merupakan suatu kunci pokok untuk mencapai cita-cita suatu bangsa (HS Dyan:2020). Pendidikan adalah sebuah aktivitas yang mempunyai maksud dan tujuan tertentu yang dilakukan secara sadar dan penuh tanggung jawab untuk dapat meningkatkan pengetahuan, keterampilan, dan nilai nilai, sehingga mampu menyesuaikan diri dengan lingkungan sekitarnya (Naibaho \& Gaol, 2021) Perkembangan Teknologi informasi di era digital sangat berpengaruh 
terhadap sistem pembelajaran yang sekarang, apalagi pada saat New Normal saat ini. Dilihat berdasarkan pergeseran pembelajaran dari teacher centered learning menuju student centered learning. Sistem pembelajaran dulu masih menggunakan metode konvensional atau teacher centered learning dimana peserta didik kebanyakan mendengarkan penjelasan ataupun keterangan materi pendidik di depan kelas dan mengerjakan tugas yang diberikan jika pendidik membagi soal latihan kepada peserta didik.

Peserta didik dan pendidik tetap menjalan KBM seperti biasanya, hanya saja dilaksanakan di tempat yang berbeda maupun terpisah dirumah masing-masing dengan menggunakan aplikasi whatsapp, dalam pembelajaran pendidik memberi tugas kepada peserta didik melalui whatsapp grup, kemudian peserta didik mengirimkan kembali tugas kepada pendidik.

Pada masa New Normal ini pelaksanaan pembelajaran masing dilakukan secara daring, semua siswa menggumpulkan tugas langsung ke sekolah. Pembelajaran daring menggunakan aplikasi whatsapp di anggap sedikit sulit, karena ketika guru menerangkan materi pelajaran ada beberapa siswa yang tidak bisa mengikuti proses kegiatan pembelajaran daring dikarenakan ada beberapa para siswa yang orangtuanya tidak memiliki Smartphone yang mengakibatkan kurangnya kemaksimalan dalam proses pembelajaran.

Pembelajaran daring sangat dikenal di kalangan masyarakat dan akademik dengan istilah pembelajaran online. Istilah lain yang sangat umum diketahui adalah pembelajaran jarak jauh. Pembelajaran daring merupakan pembelajaran yang berlangsung di dalam jaringan dimana pengajar dan yang diajarkan tidak bertatap muka secara langsung. Menurut Dr. Asep Sulaeman (2020:58) "pembelajaran daring adalah pelaksanaan kelas pembelajaran dalam jaringan untuk mencapai kelompok target yang utuh dan luas, sehingga pembelajaran daring ini dapat diselenggarakan dimana saja, kapan saja dan dapat diikuti secara gratis maupun berbayar".

Menurut Hakim (2021:136) pembelajaran daring merupakan metode belajar mengajar yang bergantung pada kemampuan, fleksibilitas, aksesibilitas jaringan internet untuk memunculkan berbagai macam interaksi pembelajaran. Berdasarkan pengertian ini, pembelajaran daring adalah suatu pembelajaran yang bergantung pada jaringan internet karena dengan adanya jaringan internet dapat terlaksananya pembelajaran daring yang semestinya.

Menurut Fitriyani, Fauzi,dan Sari (Yuliana et al., 2020:2) "pembelajaran daring adalah sebuah inovasi pendidikan yang melibatkan unsur teknologi informasi dalam pembelajaran". Berdasarkan pengertian ini, pembelajaran daring adalah suatu inovasi dalam pendidikan yang melibatkan teknologi informasi dalam melaksanakan pembelajaran.

Dari pendapat para ahli dapat di simpulkan bahwa pembelajaran daring adalah suatu pembelajaran yang dilakukan di jarak jauh atau bisa dikatakan pembelajaran daring yaitu dimana peserta dan guru tidak saling bertatap muka.

Dalam pembelajaran daring guru tidak dibatasi oleh aturan dalam memilih dan menggunakan media pembelajaran online yang akan digunakan. Artinya adalah media yang digunakan oleh guru dapat digunakan oleh siswa sehingga komunikasi dalam pembelajaran dapat dilakukan dengan baik.

Menurut Pohan (2020:11) macam macam media yang digunakan adalah E-learning, Edmodo, Google meet, V-Class, Google class, Webinar, Zoom, Skype, Webex, Facebook live, Youtube live, Schoology, What's up, Email, dan Messenger. Menurut Meda, dkk media yang digunakan saat pembelajaran daring adalah Zoom, Google Class, Whatsapp, Youtube.

Menurut Gusty et al (2020:93) media yang digunakan saat pembelajaran daring adalah Whatsapp, e-mail, dan google classroom. Menurut Yuliana et al (2020:6) media yang digunakan saat pembelajaran daring adalah Zoom, Google Class, Whatsapp, Youtube. Menurut Hadion (2021:68) macam macam media yang digunakan adalah WhatsApp, Google Classroom, Google Meet, Edmudo dan Zoom.

Berdasarkan media pembelajaran daring di atas, maka dapat di simpulkan bahwa media yang digunakan saat pembelajaran daring adalah Zoom, Youtube, Google Class, dan saat pemberian tugas guru banyak menggunakan Whatsapp. 


\section{METODE PENELITIAN}

Pendekatan dalam penelitian ini adalah pendekatan untuk menghasilkan data deskriptif berupa kata kata tertulis atau lisan dari subjek/aktor dan perilaku yang dapat diamati.

Tempat penelitian adalah tempat yang digunakan dalam melukan penelitian untuk memperoleh data yang diinginkan. Penelitian ini dilakukan di SD Free Methodist 2 Medan. Alasan peneliti mengambil tempat penelitian di Sekolah tersebut, karena peneliti ingin mengetahui peranan pembelajaran daring di Sekolah tersebut. Penulis menggunakan teknik penelitian karena menganggap lebih sesuai disamping ingin menghindari penggunaan "metode penelitian" karena sesungguhnya uraian berikut bukan berisi uraian metode semata-mata.

\section{Kata-kata dan Tindakan}

Kata-kata dan tindakan orang-orang yang diamati atau diwawancarai merupakan sumber data utama. Menurut J. Moelong (2010:157) sumber data utama dicatat melalui catatan tertulis atau melalui perekaman video/audio tapes, pengambilan foto atau film. Pencatatan sumber data utama melalui wawancara atau pengamatan berperanserta merupakan hasil usaha gabungan dari kegiatan melihat, mendengar, dan bertanya. Manakah diantara ketiga kegiatan yang dominan. Jelas akan bervariasi dari satu waktu ke waktu lain dan dari satu situasi ke situasi lainnya.

\section{Teknik Pengumpulan Data}

\section{Observasi Partisipasi}

Observasi dilakukan peneliti dengan guru kelas dan siswa kelas III SD Free Methodist 2 Medan melalui pengamatan yang dilakukan peneliti di dalam kelas dan di lingkungan sekolah. Observasi yang dilakukan berdasarkan kegiatankegiatan yang dilakukan siswa yaitu : (1) kegiatan di halaman dan taman sekolah, (2) kegiatan wali kelas, (3) kegiatan belajar siswa di kelas, (4) kegiatan belajar siswa di sekolah.

\section{Wawancara}

Wawancara digunakan sebagai teknik pengumpulan data apabila peneliti ingin melakukan studi pendahuluan untuk menemukan permasalahan yang harus diteliti, tetapi juga apabila peneliti ingin mengetahui hal-hal dari responden yang lebih mendalam. Adapun jenis wawancara yang digunakan dalam penelitian ini adalah wawancara terstruktur, dilakukan peneliti dengan guru kelas dan siswa kelas III SD Free Methodist 2 Medan melalui pertanyaan-pertanyaan yang telah disiapkan sesuai dengan permasalahan yang akan diteliti. Berhubungan dengan peranan pembelajaran daring.

\section{Dokumentasi}

Dokumentasi merupakan catatan peristiwa yang telah berlalu. Pengumpulan data dengan teknik dokumentasi ini digunakan untuk melengkapi data. Pada penelitian ini dokumentasi dapat berupa catatan, transkip, agenda, dan sebagainya yang berhubungan peranan pembelajaran daring kelas III SD Free Methodist 2 Medan.

\section{Triangulasi}

Dalam teknik pengumpulan data, triangulasi diartikan sebagai teknik pengumpulan data yang bersifat menggabungkan dari berbagai teknik pengumpulan data dan sumber data yang telah ada. Bila peneliti melakukan pengumpulan data dengan triangulasi, maka sebenarnya peneliti mengumpulkan data yang sekaligus menguji kredibilitas data, yaitu mengecek kredibilitas data dengan dengan berbagai teknik pengumpulan data dan berbagai sumber data.

(1) Triangulasi teknik, adalah triangulasi yang dilakukan dengan cara mengecek data kepada sumber yang sama dengan teknik yang berbeda

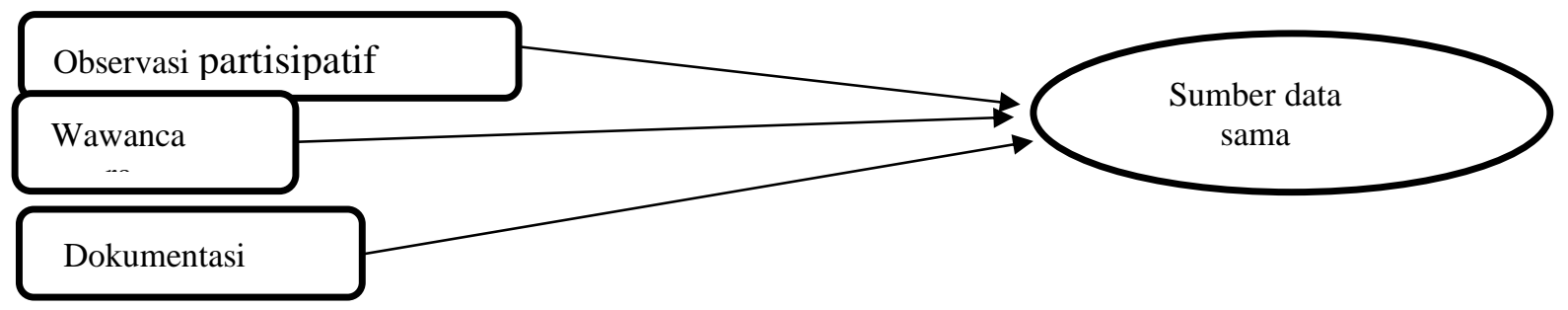

Gambar 1. Triangulasi "Teknik Pengumpulan Data (Bermacam-Macam Cara Pada Sumber Yang Sama) 
(2) Triangulasi Sumber, yakni triangulasi yang dilakukan dengan melakukan pengecekan data yang diperoleh dari beberapa sumber.

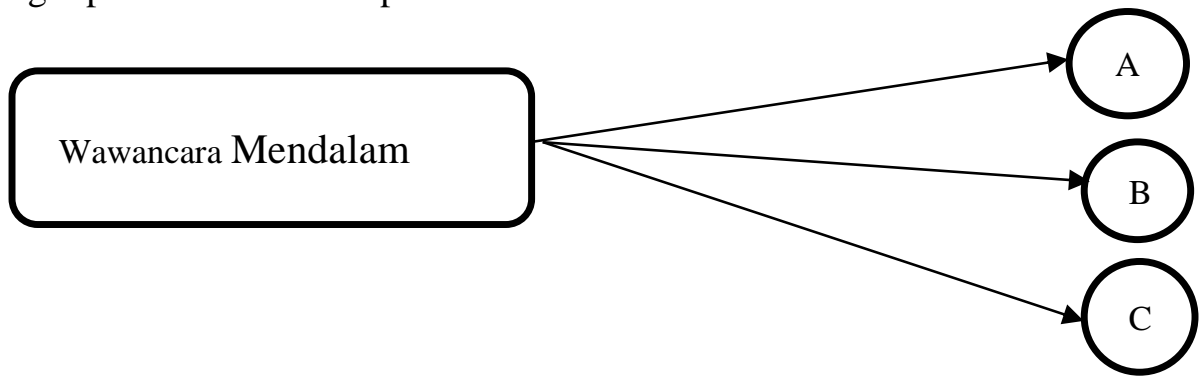

Gambar 2. Triangulasi "sumber" pengumpulan data (satu teknik pengumpulan data pada bermacam-macam sumber data $\mathrm{A}, \mathrm{B}, \mathrm{C}$ )

(3) Triangulasi Waktu, adalah teknik triangulasi yang menilai waktu juga dapat mempengaruhi kredibilitas data. Artinya untuk menguji kredibilitas data ini dilakukan dengan wawancara, observasi atau teknik lain di waktu atau situasi yang berbeda dari sebelumnya.

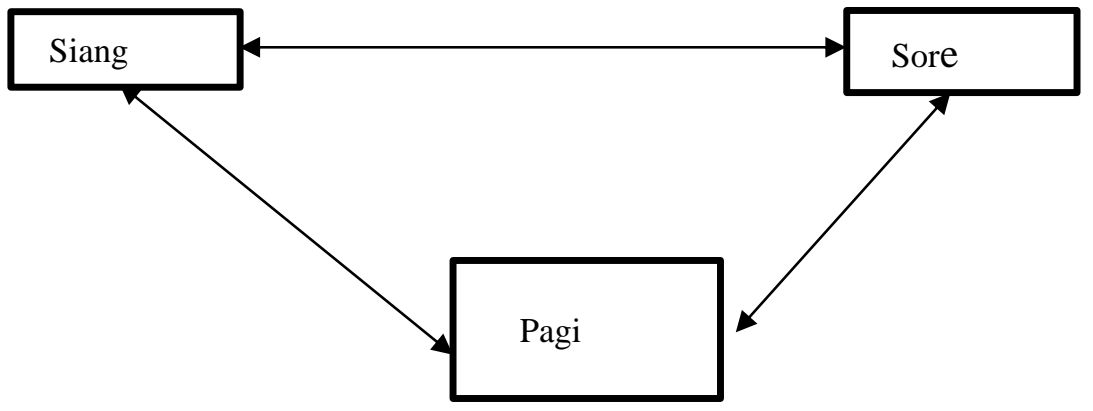

\section{Teknik Analisis Data}

Menurut Nasution (Sugiyono, 2016:245) analisis telah dimulai sejak merumuskan dan menjelaskan masalah, sebelum terjun ke lapangan, dan berlangsung terus menerus sampai penulisan hasil penelitian. Namun dalam penelitian kualitatif, analisis data lebih difokuskan selama proses di lapangan bersamaan dengan pengumpulan data. Menurut Miles dan Huberman (Sugiyono, 2016:246) aktivitas dalam analisis data kualitatif dilakukan secara terus menerus sampai tuntas, sehingga datanya sudah jenih. Aktivitas dalam analisis data yaitu data reduction, data display, dan conclusion drawing/verification, setelah peneliti melakukan pengumpulan data, maka peneliti melakukan antisipatory sebelum melakukan reduksi data

\section{Penyajian Data (data display)}

Setelah peneliti mampu mereduksi data maka langkah selanjutnya adalah mendisplay data. Penyajian data dengan penelitian kualitatif dapat dilakukan dalam bentuk table, grafik, phie card, pictogram dan sejenisnya. Melalui penyajian tersebut maka data terorganisasikan, tersusun dalam pola hubungan, sehingga akan mudah dipahami. Menurut Miles dan Huberman (Sugiyono, 2016:249) yang paling sering digunakan untuk menyajikan data dalam penelitian kualitatif adalah dengan teks yang bersifat naratif.

\section{Penarikan Kesimpulan (conclusion drawing/verification)}

Langkah ketiga dalam analisis data menurut Miles dan Huberman (Sugiyono, 2016:252) adalah penarikan kesimpulan dan 
verifikasi. Kesimpulan awal yang dikemukakan masih bersifat sementara, dan akan berubah bila ditemukan bukti-bukti kuat yang mendukung pada tahap-tahap pengumpulan data berikutnya. Tetapi bila pengumpulan data pada tahap awal didukung oleh bukti bukti valid dan konsisten saat peneliti kembali ke lapangan mengumpulkan data, maka kesimpulan yang dikemukakan merupakan yang kredibel.

\section{Pengujian Keabsahan Data}

Untuk mengetahui keabsahan data yang dikumpulkan dalam penelitian kualitatif. Teknik keabsahan data dalam penelitian ini menggunakan empat teknik meliputi uji credibility (validitas interval), transferbility (validitas eksternal), dependability (reliabilitas), dan conformability (obyektivitas).

\section{Pengujian Kredibilitas Data (credibility)}

Uji kredibilitas data atau kepercayaan terhadap data hasil penelitian kualitatif antara lain dilakukan dengan perpanjangan pengamatan, meningkatkan ketekukan, triangulasi, dan member check.

\section{Perpanjangan Pengamatan}

Perpanjangan pengamatan yaitu
keikutsertaan dalam proses penelitian. Perpanjangan keikutsertaan peneliti akan memungkinkan peningkatan kepercayaan data yang dikumpulkan. Perpanjangan keikutsertaan menuntut waktu yang cukup lama untuk peneliti terjun ke lokasi guna menditeksi dan memperhitungkan penyimpangan yang dapat mengotori data. Dipihak lain untuk membangun kepercayaan subjek kepada peneliti dan kepercayaan terhadap isi penelitian.

\section{Ketekunan pengamatan yang terus menerus}

Pada kegiatan ini pengamatan menemukan ciri-ciri dan unsur-unsur yang sangat relevan dengan isu yang sedang dicari dan selanjutnya memusatkan diri pada masalah tersebut secara rinci. Oleh sebab itu berarti peneliti mengadakan pengamatan dilokasi dengan teliti dan rinci secara berkelanjutan terhadap faktor-faktor yang dominan. Kemudian menelaahnya secara rinci sampai pada satu titik sehingga pemeriksaan pada tahap awal terlihat salah satu atau semua faktor yang ditelaah sudah dipahami dengan cara yang biasa.

\section{Pemeriksaan Teman Sejawat}

Pemeriksaan teman sejawat melalui diskusi. Hal ini dimaksudkan memberikan suatu kesempatan awal yang baik untuk memulai menjajaki dan menguji hipotesis yang muncul dari pemikiran peneliti. Dalam diskusi ini juga bisa terungkap segi-segi lainnya yang justru membongkar atau membuka pemikiran peneliti. Sebaiknya teman diskusi memiliki pengalaman dalam bidang yang di permasalahkan terutama isi dan metodologinya.

\section{Member Check}

Member check adalah proses pengecekan data yang diperoleh peneliti kepada pemberi data. Tujuan member check adalah untuk mengetahui seberapa jauh data yang diperoleh sesuai dengan apa yang diberikan oleh pemberi data. Apabila data yang ditemukan disepakati oleh pemberi data berarti datanya data valid, sehingga semakin kredibel/dipercaya, tetapi apabila data yang ditemukan peneliti dengan berbagai penafsirannya tidak disepakati oleh pemberi data, maka peneliti perlu melakukan diskusi dengan pemberi data. Setelah data disepakati bersama, maka para pemberi data diminta untuk menandatangani, supaya lebih otentik. Selain itu juga sebagai bukti bahwa peneliti telah melakukan member check Pengujian Keteralihan (transferability)

Dengan melakukan uraian rincian dari data ke teori, dari kasus ke kasus lain sehingga setiap pembaca laporan penelitian ini mendapatkan gambaran yang jelas dan dapat menerapkannya pada konteks lain yang sejenis. Dalam hal ini peneliti harus menyajikan data penelitian dengan jelas dan akurat. Sehingga memberi masukan bagi siapa saja yang membaca dan akan merasa tertarik untuk dapat dipublikasikannya pada tempat dan konteks yang lain.

\section{Pengujian Ketergantungan (dependability)}

Yaitu mengusahakan agar proses penelitian tetap konsisten dengan meninjau ulang semua aktifitas penelitian terhadap data yang diperoleh dengan memperhatikan konsisten dan 
realibilitas data. Jika dua atau beberapa kali pengulangan dalam satu kondisi yang sama dan hasilnya secara esensial sama, maka dikatakan realibilitasnya tercapai. Peneliti dalam konteks ini dapat mengadakan beberapa kali wawancara dengan wali kelas dan siswa berprestasi kepada kelas III SD Free Methodist 2 Medan dan berulang mengadakan pengamatan mencari tingkat realibilitas yang tinggi.

\section{Pengujian Kepastian (confirmability)}

Yaitu mengusahakan agar data dapat dijamin keterpercayaannya sehingga kualitas data dapat diandalkan dan dipertanggungjawabkan. Cara yang dilakukan dengan mengaudit semua data yang diperoleh untuk menentukan kepastian dan kualitas data yang diperoleh. Kepastian hasil peneliti dapat diakui oleh banyak orang secara objektif. Dalam hal ini peneliti guna menguji kevalidan data/ keabsahan data agar objektif kebenarannya sangat dibutuhkan beberapa orang narasumber sebagai informan dalam penelitian.

\author{
HASIL DAN PEMBAHASAN \\ Lembaga Pendidikan Sekolah Dasar Free \\ Methodist 2 Medan \\ SD Free Methodist 2 Medan merupakan
} salah satu sekolah dasar Swasta di bawah naungan Kementrian Pendidikan dan Kebudayaan yang berlokasi di Jl. Sekolah No. 32, Cinta Damai, Kecamatan Medan Helvetia, Kota Medan, Sumatera Utara. SD ini beroperasi pada dengan Nomor SK Akreditasi 694/BAP-SM/LL/XI/2017.

\section{Sejarah Berdiri Sekolah Dasar Free Methodist 2 Medan}

SD Free Methodist 2 Medan didirikan pada tahun 2000, tetapi surat pendirian sekolah keluar pada tahun 2003 dan keluar surat izin operasional sekolah pada tahun 2019. SD ini berlokasi di Jl. Sekolah No.32, Cinta Damai. Luas SD ini $1600 \mathrm{~m}^{2}$ dan tanah sekolah ini miliki yayasan. Kepala sekolah di sekolah ini Piade De Yure.

Tabel 1. Siswa Berprestasi TA. 2020/2021

\begin{tabular}{|c|c|c|c|c|c|}
\hline NO & Nama Siswa & Kelas & Semester & Juara & Tahun Ajaran \\
\hline & & 1 & 1 (Ganjil) & 1 & $2018 / 2019$ \\
\hline \multirow[t]{4}{*}{1} & Aura Kisya & 1 & 2 (Genap) & 2 & $2018 / 2019$ \\
\hline & & 2 & 1 (Ganjil) & 10 & $2019 / 2020$ \\
\hline & & 2 & 2 (Genap) & - & $2019 / 2020$ \\
\hline & & 1 & 1 (Ganjil) & 7 & $2018 / 2019$ \\
\hline \multirow[t]{4}{*}{2} & Rani Febby Kasih & 1 & 2 (Genap) & 1 & $2018 / 2019$ \\
\hline & Manurung & 2 & 1 (Ganjil) & 1 & $2019 / 2020$ \\
\hline & & 2 & 2 (Genap) & - & $2019 / 2020$ \\
\hline & & 1 & 1 (Ganjil) & 1 & $2018 / 2019$ \\
\hline \multirow[t]{3}{*}{3} & Nadia Larasati Sianipar & 1 & 2 (Genap) & 2 & $2018 / 2019$ \\
\hline & & 2 & 1 (Ganjil) & 3 & $2019 / 2020$ \\
\hline & & 2 & 2 (Genap) & - & $2019 / 2020$ \\
\hline
\end{tabular}

Berdasarkan tabel 1 di atas siswa siswa berprestasi ini dari kelas berbeda satu dari kelas IIIC dan dua dari kelas IIIB.

\section{Komponen Sekolah Dasar Free Methodist 2 Medan}

Pada tahun ajaran 2020/2021 siswa kelas I berjumlah 81 siswa yang terdiri dari 48 siswa laki laki dan 33 siswa perempuan, siswa kelas II berjumlah 85 siswa yang terdiri dari 50 siswa laki laki dan 35 siswa perempuan, siswa kelas III berjumlah 117 siswa yang terdiri dari 64 siswa laki laki dan 53 siswa perempuan, siswa kelas IV berjumlah 127 siswa yang terdiri dari 63 siswa laki laki dan 64 siswa perempuan, siswa kelas V berjumlah 130 siswa yang terdiri dari 62 siswa laki laki dan 68 siswa perempuan, siswa kelas VI 
berjumlah 160 siswa yang terdiri dari 78 siswa laki laki dan 82 siswa perempuan. Jumlah keseluruhan siswa SD Free Methodist 2 Medan pada tahun ajaran 2020/2021 adalah 700 siswa yang terdiri dari 365 siswa laki laki dan 335 siswa perempuan.

\section{Kurikulum dan Program Pengajaran}

Kurikulum yang dilaksanakan di SD Free

Methodist 2 Medan yaitu Kurikulum 13 menggunakan metode tematik, walaupun pada saat pandemi seperti ini SD Free Methodist 2 Medan tetap melaksanakan kurikulum 13 dan pelaksanaan pembelajaran di sekolah ini menggunakan whatsapp dimana guru mengirim modul dan video pembelajaran ke grup whatsapp dan video pembelajaran yang di kirim guru berisikan penjelasan yang lebih jelas dari modul yang dikirim guru.

\section{Ketenagaan}

Di SD Free Methodist 2 Medan tenaga pendidiknya rata rata tamatan $\mathrm{S} 1$, tetapi hanya sebagian kecil guru di sekolah ini tamatan S1 PGSD, rata rata guru di sekolah ini tamatan S1 Matematika, S1 Bahasa Indonesia, S1 PKN, dan di sekolah ini memiliki dua guru dengan tamatan S2. Walaupun di sekolah ini masih banyak guru yang tidak berkompeten dengan kata lain tidak tamatan S1 PGSD tetapi para guru masih mengikuti program yang dilaksanakan oleh sekolah.

\section{Keuangan dan Pembiayaan}

Keuangan berasal dari uang sekolah siswa yang tiap bulannya siswa membayar 150.000 dan dana bos. Pembiayaan yang rutin dilakukan oleh SD Free Methodist 2 Medan yaitu pemberian gaji guru, uang listrik, uang air, uang wifi.

\section{Hubungan Sekolah dan Masyarakat}

Hubungan warga sekolah dengan masyarakat baik, dimana masyarakat menghargai kegiatan yang dilaksanakan oleh sekolah dan masyarakat tidak pernah menggangu kegiatan belajar mengajar di sekolah tersebut dengan membuat kebisingan. Toleransi beragamanya pun bagus dimana saat masyarakat muslim yang sedang melaksanakan solat jum'at warga sekolah tidak keberatan kalau kendaraan masyarakat di parkir di daerah sekolah.

\section{Organisasi dan Tugas}

Di SD Free Methodist 2 Medan hanya memiliki organisasi pramuka saja dan biasanya setiap sabtu pagi sebelum melaksanakan kegiatan belajar mengajar guru dan siswa melakukan latihan pramuka. Dan bagi siswa yang kelas atas diwajibkan mengikuti organisasi pramuka dimana di kelas atas siswa melakukan pramuka sudah dibagi dalam beberapa regu dan akan dilaksanakan camping bagi siswa kelas atas agar siswa lebih akrab lagi.

\section{Kegiatan Proses Belajar Mengajar Sekolah Dasar Free Methodist 2 Medan}

Berdasarkan observasi peneliti selama pandemi covid 19 siswa melaksanakan belajar di rumah dan guru menyiapkan materi dan video pembelajaran. Sebelum materi dan video pembelajaran di kirim ke siswa melalui grup whatsapp guru menyapa siswa terlebih dahulu di grup setelah itu guru mengirim video pembelajaran dan modul ke grup whatsapp sesuai dengan jadwal belajar, dan biasanya guru mengirim materi dan video pembelajaran jam 08.00 wib. Setelah guru mengirim materi dan video pembelajaran siswa menonton video pembelajaran terlebih dahulu setelah itu siswa melihat materi yang dikirim oleh guru yang berisi catatan dan latihan.

Kemudian siswa mengerjakan catatan terlebih dahulu setelah itu siswa mengerjakan latihan atau tugas yang diberikan oleh guru. Setelah itu setiap hari sabtu siswa mengantarkan tugas yang telah mereka kerjakan selama 6 hari dan saat orang tua siswa mengantarkan tugas siswa ke sekolah guru tidak lupa memeriksa tugas siswanya. Setiap bulan dilakukan ujian untuk mengetahui pemahaman siswa tetapi saat ujian bulanan guru membuat ujian melalui google form, saat ujian melalui google form batas mengerjakan ujian hari sabtu dan ujian semester siswa ujian dengan diberi kertas ujian yang batas pengembalian kertas ujiannya 1 minggu (Lampiran 4).

Pada mata pelajaran bahasa indonesia, pkn, agama, sbdp guru selalu mengirimkan video pembelajaran dan modul pembelajaran. Pada mata pelajaran matematika, penjas, bahasa inggris guru jarang membuat video pembelajaran tetapi guru 
hanya mengirimkan modul atau materi pelajaran ke grup whatsapp.

\section{Keadaan Kegiatan Belajar Siswa Berprestasi \\ Berdasarkan observasi peneliti hari Senin} sampai Sabtu kegiatan belajar mengajar dilaksanakan jam 08.00 wib pertama tama guru menyapa siswa di grup lalu guru mengirimkan materi dan video pembelajaran ke grup whatsapp, kemudian siswa berprestasi menonton video pembelajaran terlebih dahulu setelah selesai menonton video pembelajaran siswa membuka materi yang diberikan oleh guru. Kemudian siswa menuliskan catatan yang diberikan oleh guru setelah itu mengerjakan latihan yang diberikan oleh guru. Saat siswa kesusahan dalam mengerjakan latihan yang diberikan oleh guru biasanya siswa berprestasi membaca catatan untuk mencari jawaban dan misalnya di jawaban tidak ada jawabannya siswa menonton kembali video pembelajaran yang dikirim oleh guru. dua siswa berprestasi belajar di dampangi oleh ibunya dan satu siswa berprestasi belajar di dampangi oleh guru lesnya. Pengumpulan tugas ke sekolah dilakukan oleh orangtua yang dilaksanakan setiap hari Sabtu. Pengumpulan tugas ke sekolah dari jam 08.00 - 11.30 wib.

\section{Pembahasan}

Berdasarkan penelitian yang telah dilakukan peneliti di SD Free Methodist 2 Medan bahwa tidak semua siswa berprestasi merasakan bahagia melakukan pembelajaran daring. Data yang diperoleh melalui observasi, wawancara, dan dokumentasi yang dilakukan peneliti pada bulan juni dan juli 2021. Informan yang diteliti adalah 3 siswa berprestasi kelas III SD Free Methodist 2 Medan.

\section{Analisis Konteks Keadaan Fisik Sekolah Dasar Free Methodist 2 Medan}

SD Free Methodist 2 Medan ini adalah Sekolah Dasar Swasta yang berlokasi di Provinsi Sumatera Utara Kota Medan Kecamatan Medan Helvetia J1. Sekolah No. 32, Cinta Damai. Dengan ukuran tanah $1600 \mathrm{~m}^{2}$ jumlah ruangan kelas dua puluh empat. Jumlah guru keseluruhan yang mengajar di SD Free Methodist 2 Medan ini sebanyak tiga puluh tujuh guru, dengan jenjang pendidikan guru rata rata $\mathrm{S} 1$ dan dua guru dengan jenjang pendidikan S2. Kurikulum yang diterapkan di sekolah ini adalah kurikulum 2013.

Di sekolah ini terdapat dua kantin. satu kantin berada di depan dan satu kantin lagi berada di belakang. Dan sekolah ini terdapat dua lapangan di mana satu lapangan berada di depan dan satu lagi berada di belakang. Di lapangan depan terdapat tanaman kecil yang memiliki bunga. Sekolah ini berada di dalam gang dan jauh dari keramaian dan membuat sekolah nyaman karena jauh dari kebisingan lalu lintas. Sarana dan prasarana yang ada disekolah ini adalah ruang guru, ruang kepala sekolah, ruang belajar, ruang perpustakaan, ruang komputer.

\section{Keadaan Atmosfir Sekolah Dasar Free Methodist 2 Medan}

Berdasarkan observasi yang telah dilakukan, peneliti melihat bahwa relasi para guru terjalin dengan baik dari cara dan sikap mereka dalam bertegur sapa antara satu dengan yang lainnya. Karena saat datang ke sekolah guru harus mengisi daftar hadir di ruangan guru dengan begitu saat guru saling berjumpa guru saling menegur dan mengucapkan "selamat pagi pak,buk". Setelah guru kelas mengisi absen guru kelas langsung masuk ke kelas masing masing dan saat di perjalanan mau ke kelas saat bertemu guru lain mereka saling mengucapkan "selamat pagi".

Berdasarkan observasi yang dilakukan peneliti, relasi guru dengan orang tua siswa terjalin dengan baik, hal ini terjadi saat orang tua siswa datang ke sekolah, guru piket menyapa orang tua dan mengingatkan orangtua untuk mengecek suhu dan mencuci tangan terlebih dahulu sebelum memasuki ruangan kelas untuk mengumpulkan tugas siswa. Saat orangtua siswa mengantarkan tugas siswa ke guru, orangtua menyapa guru wali setelah itu tugas siswa di serahkan ke guru dan guru mengembalikan buku yang diberikan oleh orangtua pada minggu lalu setelah itu orangtua pulang kembali ke rumah dan guru memeriksa tugas yang telah di kerjakan oleh siswanya.

\section{Keadaan Proses Pembelajaran Selama Pandemi di SD Free Methodist 2 Medan \\ Berdasarkan observasi yang dilakukan peneliti, selama pandemi covid 19 siswa}


melaksanakan belajar di rumah dan guru menyiapkan materi dan video pembelajaran secara online. Sebelum mengirim video pembelajaran dan materi pelajaran atau modul guru menyapa siswa terlebih dahulu setelah itu materi dan video pembelajaran yang telah siap dibuat oleh guru di kirim ke siswa melalui grup whatsapp sesuai dengan jadwal belajar, dan biasanya guru mengirim materi dan video pembelajaran jam 08.00 wib. Setelah guru mengirim materi dan video pembelajaran siswa menonton video pembelajaran terlebih dahulu setelah itu siswa melihat materi yang dikirim oleh guru yang berisi catatan dan latihan. Kemudian siswa mengerjakan catatan terlebih dahulu setelah itu siswa mengerjakan latihan atau tugas yang diberikan oleh guru. Setelah itu setiap hari Sabtu orang tua siswa mengantarkan tugas yang telah siswa kerjakan selama 1 minggu dan saat orang tua siswa mengantarkan tugas siswa ke sekolah guru tidak lupa memeriksa tugas siswanya.

Setiap bulan dilakukan ujian untuk mengetahui pemahaman siswa tetapi saat ujian bulanan guru membuat ujian melalui google form, dimana pada pagi hari jam 08.00 wib guru mengirimkan link google formnya ke grup whatsapp dan siswa mengklik link tersebut untuk melaksanakan ujian bulanan dan batas waktu siswa mengerjakan ujiannya hari Sabtu dan ujian semester siswa ujian dengan diberi kertas ujian yang diambil orang tua pada hari Senin di sekolah dan batas pengembalian kertas ujiannya hari Sabtu.

\section{Peranan Pembelajaran Daring Kelas III SD Free Methodist 2 Medan \\ Sistem Pembelajaran Sederhana}

Berdasarkan hasil wawancara yang dilakukan pada hari Jumat, 30 Juli 2021 SWB mengatakan bahwa "Karena ini pengalaman pertama kami, dengan begitu kami merasa kurang nyaman dengan pembelajaran online".

Berdasarkan hasil wawancara yang dilakukan pada hari Sabtu, 31 Juli 2021 guru mengatakan bahwa "wajar saja siswa kurang nyaman dalam belajar online, karena kurang memahami dengan materi yang kami sampaikan dan saat belajar online tidak ada terjadinya interaksi kami dengan siswa".
Berdasarkan hasil wawancara yang dilakukan pada hari Minggu, 01 Agustus 2021 orang tua mengatakan bahwa "Memang benar yang dikatakan oleh anak kami bahwa mereka kurang nyaman dengan belajar online karena mereka tidak secara langsung mendengarkan guru saat menjelaskan materi karena anak kami lebih mudah memahami jika mendengarkan guru mengajar secara langsung".

Berdasarkan hasil wawancara yang dilakukan pada hari Jumat, 30 Juli 2021 SWB mengatakan bahwa "Selama kami melaksanakan pembelajaran daring aplikasi yang kami gunakan adalah whatsapp".

Berdasarkan hasil wawancara yang dilakukan pada hari Sabtu, 31 Juli 2021 guru mengatakan bahwa "Benar yang dikatakan siswa bahwa selama belajar daring kami menggunakan aplikasi whatsapp untuk mengirimkan modul dan video pembelajaran".

Berdasarkan hasil wawancara yang dilakukan pada hari Minggu, 01 Agustus 2021 orang tua mengatakan bahwa "Benar yang dikatakan anak kami karena handphonenya kami yang megang jadi kami mengetahui hanya aplikasi whatsapp saja yang mereka gunakan saat belajar online".

Berdasarkan hasil wawancara yang dilakukan pada hari Jumat, 30 Juli 2021 SWB mengatakan bahwa "Sejauh pengalaman belajar online kami kurang memahami materi yang disampaikan oleh guru".

Berdasarkan hasil wawancara yang dilakukan pada hari Sabtu, 31 Juli 2021 guru mengatakan bahwa "Seharusnya mereka memahami materi yang kami sampaikan karena kami tidak hanya memberi modul saja tetapi kami juga memberikan video penjelasan mengenai materi yang kami sampaikan".

Berdasarkan hasil wawancara yang dilakukan pada hari Minggu, 01 Agustus 2021 orang tua mengatakan bahwa "Memang benar anak kami kurang memahami materi yang dikirim guru di grup whatsapp, karena anak kami lebih gampang memahami jika mendengarkan dan melihat guru mengajar secara langsung".

Berdasarkan hasil wawancara yang dilakukan pada hari Jumat, 30 Juli 2021 SWB mengatakan bahwa "Selama pembelajaran online 
berlangsung kendala yang kami hadapi adalah kurang memahami materi yang disampaikan guru”.

Berdasarkan hasil wawancara yang dilakukan pada hari Sabtu, 31 Juli 2021 guru mengatakan bahwa "seharusnya siswa memahami materi yang kami sampaikan karena kami mengirimkan modul dan video pembelajaran, jika siswa kurang memahami materi yang terdapat di modul siswa bisa menonton video pembelajaran kami yang kami kirim di grup karena di video pembelajaran tersebut kami menjelaskan materi dengan lebih jelas".

Berdasarkan hasil wawancara yang dilakukan pada hari Minggu, 01 Agustus 2021 orang tua mengatakan bahwa "Benar yang dikatakan anak kami, karena anak kami lebih gampang memahami jika mendengarkan dan melihat guru mengajar secara langsung".

Berdasarkan hasil wawancara yang dilakukan pada hari Jumat, 30 Juli 2021 SWB mengatakan bahwa "Selama pembelajaran daring ini kami biasanya dibantu oleh orang tua atau guru privat".

Berdasarkan hasil wawancara yang dilakukan pada hari Sabtu, 31 Juli 2021 guru mengatakan bahwa "seharusnya siswa saat belajar online seperti ini harus ada yang membantu dia atau yang membimbing mereka".

Berdasarkan hasil wawancara yang dilakukan pada hari Minggu, 01 Agustus 2021 orangtua mengatakan bahwa "Memang benar yang dikatakan oleh anak kami saat belajar daring ini kami sebagai orangtua membantu anak kami saat meminta bantuan".

\section{Sistem Pembelajaran Personal}

Berdasarkan hasil wawancara yang dilakukan pada hari Jumat, 30 Juli 2021 SWB mengatakan bahwa "Selama ini kami tidak membuat jadwal belajar personal (pribadi), tetapi kami melaksanakan belajar pribadi pada sore hari jam 18.00 wib atau malam hari jam 20.00 wib".

Berdasarkan hasil wawancara yang dilakukan pada hari Sabtu, 31 Juli 2021 guru mengatakan bahwa "seharusnya siswa berprestasi harus membuat jadwal belajar sendiri dan melaksanakan jadwal belajar yang telah dibuatnya untuk memahami kembali materi yang telah mereka pelajari”.

Berdasarkan hasil wawancara yang dilakukan pada hari Minggu, 01 Agustus 2021 orang tua mengatakan bahwa "Setahu kami, anak kami tidak membuat jadwal belajar sendiri tetapi kami sering melihat anak kami belajar sendiri pada 18.00 wib atau 20.00 wib".

Berdasarkan hasil wawancara yang dilakukan pada hari Jumat, 30 Juli 2021 SWB mengatakan bahwa "Dalam sehari biasanya kami belajar kira kira 30 menit. Misalnya kami belajar jam 18.00 wib kami selesai belajar di jam 18.30 wib atau kami belajar jam $20.00-20.30$ wib".

Berdasarkan hasil wawancara yang dilakukan pada hari Sabtu, 31 Juli 2021 guru mengatakan bahwa "Memang seperti itu sebenarnya siswa harus meluangkan waktu dalam belajar pribadi untuk lebih memahami materi pelajaran".

Berdasarkan hasil wawancara yang dilakukan pada hari Minggu, 01 Agustus 2021 orang tua mengatakan bahwa "Memang benar yang dikatakan anak kami, karena kami sering melihat anak kami belajar di sore hari atau di malam hari biasanya mereka belajar dari jam 18.00-18.30 wib atau jam 20.00-20.30 wib".

Berdasarkan hasil wawancara yang dilakukan pada hari Jumat, 30 Juli 2021 SWB mengatakan bahwa "Selama kami melaksanakan belajar pribadi kami mengalami kendala dimana kami tidak memahami materi yang kami baca dan biasanya kami bertanya kepada orang tua atau guru privat.".

Berdasarkan hasil wawancara yang dilakukan pada hari Sabtu, 31 Juli 2021 guru mengatakan bahwa "Memang benar kalau siswa mengalami kendala saat belajar pribadi sebaiknya mereka bertanya kepada orangtua".

Berdasarkan hasil wawancara yang dilakukan pada hari Minggu, 01 Agustus 2021 orang tua mengatakan bahwa "Memang benar yang dikatakan anak kami bahwa mereka menghadapi kendala, karena di saat mereka belajar pribadi mereka bertanya kepada saya mengenai yang mereka kurang memahaminya".

Berdasarkan hasil wawancara yang dilakukan pada hari Jumat, 30 Juli 2021 SWB mengatakan bahwa "Selama belajar pribadi kami 
tidak mencari materi dari buku lain. Kami hanya membaca dari buku catatan atau buku yang dari sekolah".

Berdasarkan hasil wawancara yang dilakukan pada hari Sabtu, 31 Juli 2021 guru mengatakan bahwa "Walaupun mereka tidak membaca materi dari buku lain tidak apa apa asalkan mereka benar benar membaca catatan mereka pasti mereka dapat memahami materi pelajaran".

Berdasarkan hasil wawancara yang dilakukan pada hari Minggu, 01 Agustus 2021 orang tua mengatakan bahwa "Selama saya melihat anak saya belajar personal memang benar yang dikatakan anak saya bahwa mereka belajar dari buku catatan dan buku yang diberi dari sekolah".

\section{Sistem Cepat Dalam Proses Pencarian Materi Atau Menjawab Soal}

Berdasarkan hasil wawancara yang dilakukan pada hari Jumat, 30 Juli 2021 SWB mengatakan bahwa "Ada beberapa cara yang kami lakukan dalam mengerjakan pekerjaan rumah (PR) yang diberikan oleh guru yaitu : Kami membaca setiap pertanyaan terlebih dahulu. Misalnya pada mata pelajaran : matematika, ppkn, bahasa indonesia, SBdP, agama, bahasa inggris, pjok. Kemudian kami mencari jawaban dari pertanyaan yang diberi guru di buku catatan. Misalnya pada mata pelajaran : matematika, ppkn, bahasa indonesia, SBdP, agama, bahasa inggris, pjok. Jika tidak ada di buku catatan, kami biasanya menonton kembali video yang dikirim oleh guru. Misalnya pada mata pelajaran : bahasa indonesia, ppkn, SBdP, agama. Kalau kami belum mengetahui pertanyaannya kami bertanya kepada orang tua atau guru privat".

Berdasarkan hasil wawancara yang dilakukan pada hari Sabtu, 31 Juli 2021 guru mengatakan bahwa "Memang begitu karena kami saat membuat pertanyaan pasti jawabannya ada di catatan".

Berdasarkan hasil wawancara yang dilakukan pada hari Minggu, 01 Agustus 2021 orang tua mengatakan bahwa "Memang benar yang dikatakan oleh anak saya karena saya mengajari mereka kalau mengerjakan pekerjaan rumah (PR) harus terlebih dahulu membaca di buku catatan kalau tidak ada mendengarkan kembali penjelasan yang di buat guru dalam video".

Berdasarkan hasil wawancara yang dilakukan pada hari Jumat, 30 Juli 2021 SWB mengatakan bahwa "Kendala yang kami hadapi saat mengerjakan pekerjaan rumah (PR) adalah jawabannya tidak ada di catatan. Pada hari senin kami belajar agama dan pjok, dimana pada pelajaran agama kadang kadang kami menghadapi kendala seperti mencari nama nama nabi yang tidak terdapat pada catatan dengan begitu kami mencari jawabannya dari google. Pada pelajaran pjok, kadang kadang bapak itu membuat pertanyaan yang jawabannya tidak ada di catatan jadi kami bertanya kepada orangtua atau guru privat dan orangtua atau guru privat yang mencari jawabannya di google setelah orangtua mendapatkan jawabannya orangtua memberi tahu jawabannya kepada kami. Pada hari selasa kami belajar bahasa indonesia, dimana pada pelajaran bahasa indonesia kami menghadapi kendala untuk membuat sebuah puisi dengan begitu kami menggunakan google untuk mencari jawaban yang dibimbing oleh orangtua atau guru privat. Pada hari rabu kami belajar ppkn, dimana pada pelajaran ppkn kami menghadapi kendala untuk membedakan pengamalan sila kedua dan keempat dengan begitu kami menggunakan google untuk mencari jawaban yang dibimbing oleh orangtua atau guru privat. Pada hari kamis kami belajar bahasa inggris, dimana pada pelajaran bahasa inggris kami menghadapi kendala untuk mengartikan sebuah kata dengan begitu kami menggunakan google untuk mencari jawaban yang dibimbing oleh orangtua atau guru privat. Pada hari jumat kami belajar metamatika, dimana pada pelajaran matematika kami menghadapi kendala untuk mengerjakan latihan yang diberi guru karena kurang memahami bagaimana mengerjakannya dengan begitu kami menggunakan google dan youtube untuk mencari jawaban yang dibimbing oleh orangtua atau guru privat. Pada hari sabtu kami belajar SBdP, dimana pada mata pelajaran SBdP kami menghadapi. Misalnya ibu guru memberi tugas kepada kami untuk bernyanyi dengan begitu kami menggunakan google dan youtube untuk mencari 
jawaban yang dibimbing oleh orangtua atau guru privat.".

Berdasarkan hasil wawancara yang dilakukan pada hari Sabtu, 31 Juli 2021 guru mengatakan bahwa "Memang benar yang dikatakan siswa karena pertanyaan yang kami buat kadang kadang tidak ada di catatan jadi membuat siswa harus meminta bantuan kepada orangtua saat mengerjakan tugas".

Berdasarkan hasil wawancara yang dilakukan pada hari Minggu, 01 Agustus 2021 orang tua mengatakan bahwa "Memang benar yang dikatakan oleh anak kami karena kami mengatakan kalau jawabannya tidak ada di catatan atau di video bertanya kepada orangtua supaya kami sebagai orangtua dapat membantu anak kami dalam mengerjakan PR nya".

Berdasarkan hasil wawancara yang dilakukan pada hari Jumat, 30 Juli 2021 SWB mengatakan bahwa "Kami kadang kadang mencari materi pelajaran dari google karena handphone yang kami gunakan itu adalah handphone ibu kami, dengan begitu handphonenya lebih sering digunakan oleh ibu kami”.

Berdasarkan hasil wawancara yang dilakukan pada hari Sabtu, 31 Juli 2021 guru mengatakan bahwa "Sebenarnya harus karena dengan mencari materi pelajaran di google dapat menambah pemahaman siswa".

Berdasarkan hasil wawancara yang dilakukan pada hari Minggu, 01 Agustus 2021 orang tua mengatakan bahwa "Memang benar begitu, apalagi saat saya ada pekerjaan saya menyuruh mereka untuk mencari di google saja”. Berdasarkan hasil wawancara yang dilakukan pada hari Jumat, 30 Juli 2021 SWB mengatakan bahwa "Kami saat mengerjakan soal soal yang diberi guru kadang kadang menggunakan google kalau jawabannya tidak ada di catatan".

Berdasarkan hasil wawancara yang dilakukan pada hari Sabtu, 31 Juli 2021 guru mengatakan bahwa "Sebenarnya tidak perlu karena kebanyakan kami membuat soal yang jawabannya ada di catatan".

Berdasarkan hasil wawancara yang dilakukan pada hari Minggu, 01 Agustus 2021 orang tua mengatakan bahwa "Memang benar begitu, apalagi saat saya ada pekerjaan saya menyuruh mereka untuk mencari di google saja".
Berdasarkan hasil wawancara yang dilakukan pada hari Jumat, 30 Juli 2021 SWB mengatakan bahwa "Kami biasanya mencari informasi tambahan dari orangtua".

Berdasarkan hasil wawancara yang dilakukan pada hari Sabtu, 31 Juli 2021 guru mengatakan bahwa "Memang seharusnya demikian agar siswa lebih gampang dalam memahaminya".

Berdasarkan hasil wawancara yang dilakukan pada hari Minggu, 01 Agustus 2021 orang tua mengatakan bahwa "Memang benar yang dikatakan oleh anak kami, karena mereka sering bertanya kepada kami”.

\section{Temuan Hasil Penelitian}

Berdasarkan hasil observasi, wawancara dan dokumentasi yang dilakukan oleh peneliti, maka peneliti selanjutnya akan mengungkapkan hasil temuan di lapangan berdasarkan fokus penelitian sebagai berikut.

\section{Sistem Pembelajaran Sederhana}

Sebaiknya aplikasi yang digunakan saat pembelajaran daring jangan hanya menggunakan WhatsApp tetapi guru harus menggunakan YouTube juga, agar siswa lebih gampang memahami materi yang diberikan oleh guru. Dan sebaiknya semua guru juga membuat video pembelajaran yang dimasukkan ke youtube jangan hanya memberi modul karena siswa kurang memahami kalau diberikan hanya modul saja. Saat memberi modul materinya jangan sedikit buatlah penjelasannya yang jelas agar siswa lebih gampang memahaminya.

\section{Sistem Pembelajaran Personal}

Siswa berprestasi melakukan pembelajaran personal atau belajar sendiri biasanya siswa berprestasi melaksanakan belajar sendiri itu di malam hari, mereka melakukan belajar sendiri untuk memahami kembali materi yang telah mereka pelajari. Misalnya mereka kurang memahami materi yang diajarkan oleh guru mereka akan bertanya kepada orangtua atau kepada orang yang lebih tua darinya. Dan mereka melakukan belajar sendiri kira kira 30 menit setiap hari. 


\section{Sistem Cepat Dalam Proses Pencarian Materi Atau Menjawab Soal}

Sebaiknya saat guru memberi modul harus jelas dan saat guru memberi pertanyaan sebaiknya jawaban dari pertanyaan yang diberikan terdapat pada catatan agar siswa lebih terbiasa membaca dari catatan. Karena video pembelajaran yang guru berikan ke grup kadang di hapus oleh orangtua karena memori hp penuh jadi sebaiknya video pembelajaran di buat di youtube biar siswa gampang mencarinya. Dan biasanya siswa menggunakan google untuk mengerjakan soal soal yang diberikan oleh guru. Kalau dari google tidak dapat mereka akan bertanya kepada orangtua atau kepada orang yang lebih tua darinya.

\section{SIMPULAN DAN REKOMENDASI}

Berdasarkan penelitian yang telah dilakukan di SD Free Methodist 2 Medan, dapat diambil kesimpulan bahwa, pembelajaran daring efektif dilaksanakan saat adanya pandemi karena untuk memutus penularan virus corona. Dan sebaiknya guru kalau membuat modul materinya harusnya lengkap jangan pula saat membuat pertanyaan siswa mencari jawaban dari google, karena saat pandemi ini sebaiknya siswa dilatih untuk mencari jawaban dari catatannya saja. Lalu sebaiknya saat masa pandemi ini guru harus berperan aktif kepada siswa, dimana guru melakukan videocall sama siswanya jangan hanya mengirim tugas di grup WhatsApp saja.

Siswa berprestasi merasa bosan dengan pembelajaran daring, karena mereka tidak mengerti materi yang diberikan oleh guru. Yang mereka tahu hanya menulis catatan yang diberikan guru, mengerjakan latihan dan menonton video pembelajaran. Sebaiknya semua guru saat membuat materi pelajaran harus disertai dengan video pembelajaran yang dimasukkan ke youtube agar siswa lebih mudah memahami materi yang disampaikan oleh guru dan video pembelajaran yang di kirim guru tidak hilang atau tidak di hapus. Hasil pembahasan dari penelitian yang sudah dilakukan oleh penelit di SD Free Methodist 2 Medan menyebutkan bahwa pembelajaran daring efektif dilaksanakan saat pandemi untuk memutuskan rantai virus corona dan siswa berprestasi merasa bosan dengan pembelajaran daring karena mereka kurang memahami materi yang diberikan oleh guru. Mereka lebih memahami jika saat diberikan materi dijelaskan atau diterangkan oleh guru karena menurut mereka lebih gampang memahami saat dijelaskan atau diterangkan oleh guru karena saat pembelajaran daring orangtua tidak mampu untuk menjelaskan materi yang diberikan oleh guru. Yang orangtua tahu hanya siswa telah siap menulis catatan dan latihan yang diberikan oleh guru, orangtua tidak memaksakan untuk anaknya memahami materi yang diberikan oleh guru.

\section{DAFTAR PUSTAKA}

Asep, S. (2020). Pemberdayaan Masyarakat di Era New Normal Pandemi Covid-19. Jakarta: Alfabeta.

Akhyak. (2021). Akademisi Dalam Lingkaran Daring. Jakarta: PT Gramredia.

Gusty, S., Nurmiati, Sulaiman, O. K., Ginantra, N. L. W. S. R., Leuwol, N. V., Sahabuddin, A. A. A., Hastuti, P., Setiantio, A. Y., Metanfanuan, T., Uktolseja, L. J., Jamaludin, Gaspersz, S., Karwanto, Rante, E., \& Warella. (2020). Belajar Mandiri: Pembelajaran Daring di Tengah Pandemi Covid-19 (JannerSimarmata (ed.)).

Hakim, R. T. Y. Al. (2021). Pembelajaran Online di Tengah Pandemi Covid-19, Tantangan yang Mendewasakan. Jurnal Ilmiah Aquinas, 2, 231-248.

Makki, M. I., \& Aflahah. (2017). Konsep Dasar Belajar dan Pembelajaran. Jakarta: Alfabeta.

Moh.Suardi. (2018). Belajar dan Pembelajaran. Jakarta: Alfabeta.

Naibaho, M. R., Gaol, R. L., \& Silaban, P. J. (2021). Pengaruh Model Contextual Teaching and Learning Dengan LKS Terhadap Hasil Belajar Siswa. Jurnal Aquinas, 6(2), 262-268.

Padangsidimpuan, I. (2017). Belajar DAN Pembelajaran Aprida Pane Muhammad Darwis Dasopang. Jurnal Aquinas, 03(2), 333-352.

Pohan, A. E. (2020). Konsep Pembelajaran Daring Berbasis Pendekatan Ilmiah. Jakarta: PT Gramedia.

R. Gilang. (2020). Pelaksanaan Pembelajaran Daring di Era Covid-19. 
Sarwa. (2021). Pembelajaran Jarak Jauh: Konsep, Masalah dan Solusi. Jurnal Aquinas, 6 (1), $100-112$.

Sugiyono. (2016). Metode Penelitian Kuantitatif, Kualitatif dan R \& D. Jakarta: Alfabeta.

Sugiyono. (2020). Metode Penelitian Kuantitatif \& Kualitatif. Jakarta: PT Gramedia.

Wijoyo, H. (2021). Efektivitas Proses Pembelajaran di Masa Pandemi. Jurnal Aquinas, 5(2), 70-80.

Yuliana, M., Simarmata, J., Mahawati, S., Sudra, R. I., Dwiyanto, H., Irawan, E., Ardiana, D. P. Y., Muttaqin, \& Yuniwati, I. (2020). Pembelajaran Daring untuk Pendidikan Teori dan Penerapan. Jurnal Aquinas, 6(2), 80-89. 